\title{
Potencial management of waste phosphogypsum with particular focus on recovery of rare earth metals
}

\author{
Kinga Podbiera-Matysik, Katarzyna Gorazda, Zbigniew Wzorek \\ Cracow University of Technology, Department of Inorganic Chemistry and Technology, ul. Warszawska 24, \\ 31-155 Cracow, Poland \\ "Corresponding author: e-mail: kingapm@chemia.pk.edu.pl
}

\begin{abstract}
Phosphogypsum is a noxious industrial waste contributing to global environmental and economic problems. This publication focuses above all on phosphogypsum resulting from the processing of apatite as a phosphorus bearing compound, since it contains considerable amounts of lanthanides due to its magma origin. The possibilities of its waste-free processing are large, however they require the application of suitable technologies, frequently expensive ones, and allowing for the individual characteristics of the given waste. The research works conducted so far confirm the possibility of applying phosphogypsum for the recovery of lanthanides, and the process enhances the removal of remaining impurities, thanks to which the purified calcium sulphate (gypsum) may find application for the production of construction materials.
\end{abstract}

Keywords: phosphogypsum waste, phosphogypsum conversion, rare earth elements, environmental threats.

\section{INTRODUCTION}

Phosphogypsum is a by-product generated during the process of obtaining phosphoric acid with the wet method. Depending on the conditions, in which the process is conducted, calcium sulphate is present in the form of anhydrite, hydrate and dihydrate, and its participation in the final product amounts to $1: 4\left(\mathrm{H}_{3} \mathrm{PO}_{4} / \mathrm{CaSO}_{4}\right.$ mass ratio) ${ }^{1}$. The most important threats connected with phosphogypsum storage, include the possibility of leaching dangerous substances (phosphates, fluorides, heavy metals, radioactive elements) that constitute a threat to the fauna and flora of local water bodies ${ }^{2}$. A considerable amount of waste generated during the process as well as the problem of its management resulted in gradual discontinuing of domestic production and a partial replacement by importing $\mathrm{H}_{3} \mathrm{PO}_{4}$. In 2012 the costs of phosphogypsum waste storage in Poland amounted to $10.70 \mathrm{PLN} / \mathrm{Mg}$, which leads to the amount of PLN 18 million per annum, considering the current scale of production. Projections for the following years do not indicate a decrease in the amounts of generated phosphogypsum waste. On the contrary, an increase of as much as 10 per cent is anticipated within the next 10 years. $^{3}$.

At present only Grupa Azoty Zakłady Chemiczne "Police" SA, a chemical plant near Szczecin, is involved in processing of phosphorus bearing raw material by applying both phosphorites and apatites in the production of phosphoric acid with the extraction method. Although production has been terminated at both Zakłady Chemiczne "Wizów" S.A., a chemical plant near Bolesławiec, and Gdańskie Zakłady Nawozów Fosforowych "Fosfory" S.A. (a plant in Gdańsk), the plants have accumulated significant amounts of phosphogypsum waste, which at present are stored for recultivation as refuse heaps. However, only a heap in Zakłady Chemiczne "Wizów" S.A is fully created from waste after apatite processing and is the main point of our research interest.

Any efficient method of phosphogypsum neutralization during the current production has been found until today - therefore, it is justified to search for alternative methods of management of the existing and ever grow- ing phosphogypsum heaps in Poland. Processing the phosphogypsum waste is undoubtedly beneficial, as it contributes to the natural environment protection and additionally permits to obtain valuable secondary raw materials, such as rare earths concentrates, which have been widely applied in metallurgical, glass, motor, and even pharmaceutical industries. Since 2010 import of lanthanides has become more and more difficult, due to the situation on the global raw material market. China, the principal potentate in this field, controlling as much as 31 per cent of global resources of these metals, dramatically decreased their export at the same time increasing a unit price and the shipment costs. Such actions have resulted in protests from the US and Russian governments and EU representatives. Petitions have been sent to the World Trade Organisation against China's actions, which, however has not bring about the intended effect. In 2010 the demand for the rare earths reached $134000 \mathrm{Mg}$, however China exported only 8000 $\mathrm{Mg}$ annually in spite of the extraction level ensuring continuous production ${ }^{4-6}$. As a result, the lanthanides reserves have dropped dramatically, reducing many producers' production capacity.

\section{LANTHANIDES APPLICATION}

The research on alternative raw materials for Lanthanides production have been applied among others in modern technologies, the so-called high-tech. Cars produced at present, e.g. Toyota Prius, may contain in their mass up to a dozen or so kilograms of rare earths, which exert a beneficial influence on metallic elements enhancing their hardness, crack resistance and general wear. In cars mechanics REE (Rare Earth Elements) compounds are applied in the production of electrical engines (hybrid NiMH battery - contains lanthanum and cerium additives; engine - contains terbium, dysprosium, neodymium, praseodymium), vehicle catalysts (lanthanum, cerium), UV windscreens (cerium), front light glasses (neodymium) and LCD screens (europium, yttrium, cerium $)^{7-8}$. Nanoparticles of cerium borate, with a diameter of $50 \mathrm{~nm}$, are applied as oil additives, thus 
beneficially influencing the coefficient of friction and anti-wear properties of oil'?

In metallurgy REO (Rare Earth Oxides) are widely applied to enhance an alloy resistance to welding. They cause spheroidization of carbides (combining good casting properties of cast iron and plasticity of cast stee $1^{10}$ ), which as a result enhances the quality of a produced alloy. Rare earth elements are also added to the material of rolls used in the process of steel rolling thanks to which the steel ignition point is lowered, and the rolls become more resistant, not only to mechanical damage but also to high temperature. In this case REO do not affect the phase system of carbides, but only reduce their need in steel $^{11}$. It has also been confirmed that metals doped with cerium compounds $\left(\mathrm{Ce}_{2} \mathrm{O}_{3}, \mathrm{Ce}_{2} \mathrm{O}_{2} \mathrm{~S}\right)$ or lanthanum compounds $\left(\mathrm{LaAlO}_{3}\right)$ have a beneficial impact on resistance to abrasion, cracking, plastic deformations and scratches ${ }^{\mathbf{1 2}-\mathbf{1 3}}$. Investigations are carried out on the possibility of replacement of beryllium admixtures with yttrium compounds, which in magnesium alloys enhance resistance to oxidation, and in zinc alloys the tensile strength and elongation resistance are improved ${ }^{\mathbf{1 4}}$.

Yttrium oxysulphides as luminophores have been applied in the production of colour TV sets and flat panel displays, electronic thermometers, or fluorescent lamps ${ }^{15-16}$.

Lanthanum carbonate has been applied in biotechnology and medicine, and thanks to its ability to bind phosphates, it may be applied while treating hyperphosphatemia, a chronic kidney disease, leading to the disturbance of calcium-phosphate regulation. The medicament known on the market as Fosrenol ${ }^{\circledR}$ has been considered safe, and additionally, it has been proved that it has a protective influence on the osseous system ${ }^{17-18}$. It was discovered, while conducting previous research work, that also dysprosium compounds possess protective properties with regard to the osseous system - osteogenic effect on bone marrow cells ${ }^{19}$.

In China investigations have been carried out on the properties of HGCe fibres containing such ingredients as gelatine and a cerium additive. Improved hydrophobic and mechanical properties of the fibre have been confirmed, and their smooth surface, compact structure, antibacterial properties and good biocompatibility, permit to assume that these fibres may find an application in biomedicine $\mathrm{e}^{\mathbf{2 0}}$.

\section{THE USE OF WASTE PHOSPHOGYPSUM IN THE WORLD}

Among the studies conducted so far on waste phosphogypsum utilization, the wide possibilities of its use in construction materials: brick, Portland cement and clinker, should pay attention. Such solutions mainly use waste phosphogypsum, as well as combinations of phosphogypsum and granulated blast-furnace slag with limestone ${ }^{\mathbf{3 4}}$. In most cases, phosphogypsum requires preliminary treatment, aimed at reducing the content of $\mathrm{P}_{2} \mathrm{O}_{5}$ and fluorine compounds, which could adversely affect the strength of the final products.

In some research, dehydration and recrystallization was used to remove impurities from phosphogypsum. These actions allow to strengthen the microstructure of the bricks, which significantly affect their strength. Bricks produced from phosphogypsum autoclaved in lower temperatures, in relation to the bricks obtained from the combination of phosphogypsum autoclaved in high temperature, were characterized by improved compressive strength, temperature variations or weight loss 22 .

In China, using waste phosphogypsum for preparation of adobe bricks were proposed. The "green bricks" were composed of phosphogypsum (75\%), river sand (19.5\%), Portland cement (4.0\%) and slaked lime (1.5\%). Proposed process of "hydration-recrystallization" consist of the following steps: formation of the bricks at a pressure of $20-40 \mathrm{MPa}$, wet curing, drying at $180^{\circ} \mathrm{C}$ for dehydration of $\mathrm{CaSO}_{4} \cdot 2 \mathrm{H}_{2} \mathrm{O}$ to $\mathrm{CaSO}_{4} \cdot 0.5 \mathrm{H}_{2} \mathrm{O}$, immersion in water for recrystallization of $\mathrm{CaSO}_{4}$ and drying. Very good results on compressive strength, water-saturated compressive strength and bending strength were observed in prepared bricks ${ }^{31}$.

In Turkey, where the annual production of phosphogypsum reaches $3,000,000 \mathrm{Mg}$ the use of waste as an additive for stabilization of the dried bricks was proposed. Such operation positively affects the resistance to softening, when exposed to water and reduces the shrinkage during drying. The best results were observed with the addition of $25 \%$ of phosphogypsum. Additionally produced material does not negatively affect the environment ${ }^{30}$.

In the technology of Portland cement production, phosphogypsum was used as a retarder, as well as a factor lowering the firing temperature: the addition of $10 \%$ of phosphogypsum helped to reduce the process temperature from $1470^{\circ} \mathrm{C}$ to $1200^{\circ} \mathrm{C}$, which significantly affects the growth of plant productivity ${ }^{32,33}$.

Russian patent also propose using purified phosphogypsum in the production of building materials. After treatment of phosphogypsum with sulfuric acid, rare earth metals are precipitated from the resulting solution by the introduction of oxalic acid. After neutralization with sulfuric acid solution to a $\mathrm{pH}$ value of $1.0-2.5$, the oxalate residue is separated from the mother-liquor solution, and is rinsed, dried and calcined. After separation from the sulfuric acid solution, the solid phosphogypsum phase is also rinsed with water ${ }^{\mathbf{4 5}}$.

The use of waste phosphogypsum in agriculture is also reported. As a mineral additive to feed products, phosphogypsum increase the phosphorus content in bones of hens and in egg shells. It is preferred to use $1 \%$ addition of phosphogypsum. These studies were carried out on the waste from the production of wet phosphoric acid, but with the Tunisian phosphate ${ }^{35}$. In the Chinese patent, 5-15\% addition of phosphogypsum to mineral fertilizer production was proposed. Other components of the fertilizer were as followed: active medical stone (10-30\%) subjected to activating treatment, active phosphorus slag (15-60\%) subjected to activating treatment and raw materials such as phosphogypsum, amino acid (5-10\%), diatomite, citric acid (5-10\%) and asparaginic acid. The mineral fertilizer is reported to have multifunctional properties like: complete in nutrition, good rapid/sustained-release effects, improved fertilizer utilization rate, low consumption of fertilizer and water and improving saline alkali soil ${ }^{\mathbf{4 6}}$. 


\section{REVIEW OF METHODS APPLIED TO RECOVER RARE EARTHS}

In nature, lanthanides occurred in the form of numerous minerals, but their concentration in the ore is low. Resources in Poland consist of $1.55 \%$ REO (Rare Earth Oxides) and are located in Bogatynia, while less rich deposits are located near Szklarska Poręba in which content of REO is up to $0.55 \%$. The most important minerals include Monazite (Ce, $\mathrm{La}) \mathrm{PO}_{4}$, Bastnaesite $(\mathrm{La}, \mathrm{Ce}) \mathrm{CO}_{3} \mathrm{~F}$ and Xenotime (Y) $\mathrm{PO}_{4}$. Pretreatment of Monazite is carried out by the gravitational, electromagnetic or electrostatic separation of Monazite concentrate from sand and other impurities. The obtained concentrate is treated in an alkaline or acidic process, that involves heating with $70 \% \mathrm{NaOH}$ or $93 \%$ $\mathrm{H}_{2} \mathrm{SO}_{4}$ respectively, followed by leaching with water. The precipitated hydroxides or dissolved sulfates of lanthanides and thorium are separated by filtration. In order to concentrate Bastnaesite ore, flotation method is used. The concentrate is than treated with $10 \% \mathrm{HCl}$. Insoluble material, where content of REO is around $70 \%$, may be used as an commercial product, or can be subjected to further thermal processing and dissolving in $10 \% \mathrm{HCl}^{40-42}$.

This publication focuses above all on phosphogypsum resulting from the processing of apatite as a phosphorus bearing compound, since it contains considerable amounts of lanthanides due to its magma origin. The method of phosphoric acid production is also an important aspect, as in the hemihydrate method almost 100 per cent of rare earth elements are transferred to phosphogypsum waste, whereas in the dihydrate method - only 75 per cent ${ }^{2}$.

The available literature provides information on the possibilities of lanthanides recovery only from phosphogypsum or sediments formed during phosphoric acid production $^{36}$. The method for extracting lanthanides with $0.14 \mathrm{~mol} / \mathrm{dm}^{3} \mathrm{HNO}_{3}$ directly from apatite ore or granite rocks is also known. However, the process appears to be economically disadvantageous due to the ore pollution, and significant quantities of phosphorus compounds important for phosphoric acid industry ${ }^{37}$. An alternative source of rare earth metals are also electro-waste, however, the technologies of their recovery are still under investigation $^{38-39,43}$.

In Poland the research works on apatite phosphogypsum were initiated at the end of the 1980s at Wrockaw University of Technology and Cracow University of Technology. The possibility of isolating impurities from calcium sulphate was analysed, its subsequent application as a secondary raw material as well as the recovery of rare earths. A few attempts were carried out with the intention of extracting lanthanides from phosphogypsum, among others by applying concentrated sulphuric acid, nitric acid or a mixture of both. The effect of leaching is based on the phase transition of hemihydrate to hydrate through the process of calcium sulphate dissolution and its subsequent crystallization. Phosphogypsum free from impurities was then subjected to filtration, and the filtrate was directed for further purification. The following methods of isolating rare earths have been identified:

- precipitation methods, which make use of the fact that in spite of their low concentration lanthanides can precipitate as sparingly soluble compounds, primarily hydroxides, oxalates or double sodium-lanthanum sulphates (Fig. 1);

- extraction methods in liquid-liquid systems with the participation of an organic phase, e.g. Rukanol PIO (approximately equimolar mixture of mono-2-ethylhexylphosphoric and di-/2-ethylhexyl/-phosphoric acids), NPPA acid (equimolar mixture of mono- and di- esters of nonyl phenyl phosphoric acid) (Fig. 2);

- crystallization methods of calcium sulphate with a simultaneous inclusion of rare earths into calcium sulphate crystal through concentration ${ }^{1,21}$. The conducted research confirmed a better efficiency of leaching lanthanides from phosphogypsum with the application of nitric acid (even as much as 90 per cent) than in the case of sulphuric acid ( $\sim 60$ per cent). However, the other analyzed process involved the generation of additional waste in the form of calcium nitrate solution, for which no application was found. The method of concentration by removing water turned out to exert a beneficial influence on the isolation of rare earths from phosphogypsum pulp. However the incurred costs related to heating of the solution dominated among production costs, which rendered the process unprofitable. As far as the applied extractants were concerned, the best effects were observed for Rukanol PIO diluted with kerosene.

Extraction of phosphogypsum with nitric acid was also proposed by Szczecin University of Technology. Phosphogypsum was dissolved until a saturated solu-

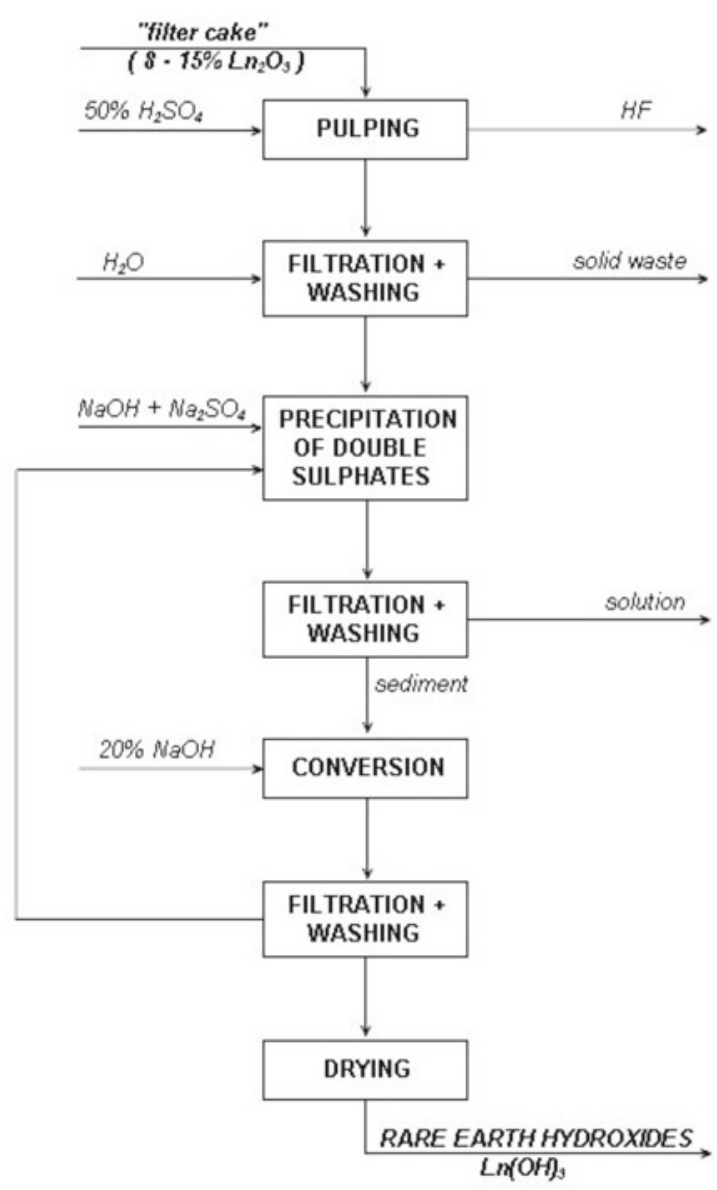

Figure 1. Precipitation method of isolating rare earths in the form of hydroxides ${ }^{21}$ 


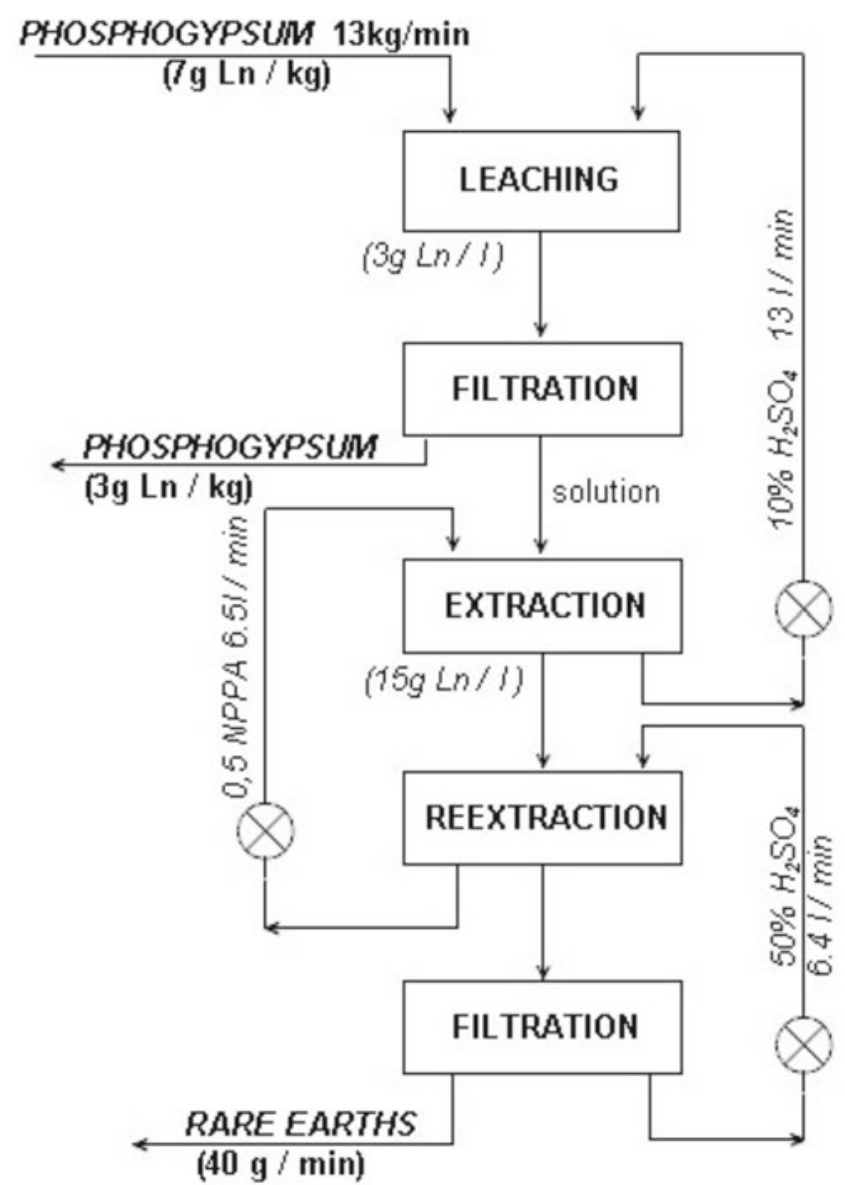

Figure 2. Extraction method of isolating rare earths with the application of NPPA extractant ${ }^{21}$

tion of calcium sulfate in dissolution temperature was obtained. Than $\alpha$-hydroxy acid was added, which results in the formation of complexes of rare earth elements. After lowering the temperature to $20-25^{\circ} \mathrm{C}$, calcium sulphate crystallizes from the solution. The calcium sulfate crystals were separated from the solution by filtration. The remaining solution of nitric acid containing rare earth complexes, were concentrated by recycling it into multiple phosphogypsum dissolving ${ }^{44}$.

The worldwide research focused also on the possibility of applying solvent extraction with the use of organic solvents, including a $\mathrm{D}_{2}$ EHPA extractant (diethyl hexyl phosphoric acid) dissolved in kerosene. This compound may be applied in an extremely acidic environment, and the best effects of the separation were observed with a higher concentration of the extractant $(\max 2 \mathrm{~mol} / \mathrm{l})$, larger coefficient of the liquid/solid body phase distribution (ratio 4:1), stoichiometric coefficient of $\mathrm{H}_{2} \mathrm{SO}_{4}$ to $\mathrm{CaO}$ equal to 1.05 , lower temperatures $(\max 343 \mathrm{~K}$ ) - exothermic reaction and a higher concentration of present phosphoric acid. Leaching efficiency increased from 32 per cent to 75 per cent, whereas by analogy the $\mathrm{P}_{2} \mathrm{O}_{5}$ content changed from 5 per cent to 25 per cent, which resulted in lower energy $\operatorname{costs}^{23}$. Literature on the subject also mentions possible applications of a $\mathrm{D}_{2}$ EHPA solvent together with $\mathrm{HNO}_{3}$ for the formation of a liquid membrane in which the inner phase is composed of the following solutions: $\mathrm{HCl}, \mathrm{HNO}_{3}$ and $\mathrm{NaOH}$. These research works helped to determine the optimal conditions to conduct the process of neodymium extraction in $4.0 \mathrm{~mol} / \mathrm{L} \mathrm{HNO}_{3}$, the voluminal ratio of the solution in the membrane to the expelled liquid equal to 1.0 , the concentration of the $\mathrm{D}_{2} \mathrm{EHPA}$ extractant equal to $0.100 \mathrm{~mol} / \mathrm{l}$ in the recirculated phase, and $\mathrm{pH} 4.60$ in the feeding phase. Under such optimal conditions for the process one achieved the recovery of 92.9 per cent neodymium within $75 \mathrm{~min}$.

A significant benefit for such a process is the possibility of conducting leaching on both concentrates and purified substances ${ }^{24}$. Also the application of the mixture of $\mathrm{D}_{2} \mathrm{EHPA}$ (di-(2-ethylhexyl)phosphoric acid) with TBP (tributylphosphate) in kerosene results in the recovery of 89.9 per cent of lanthanides with the purity of 96 per cent. The reaction consists in filtering off a residual phosphoric acid, separating radioactive compounds through their precipitation with oxalic acid and removing fluorine compounds (Fig. 3). Rare earths should be removed from the solution before the subsequent crystallization of gypsum through filtering and washing with water, and precipitation with the use of oxalic acid applied in excess. One confirmed the dependence between ionic radius and the possibility of inclusion of various elements in the structure of calcium sulphate - the closer the ionic radius to the ionic radius of calcium the greater the possibility of inclusion in the structure of sulphate ${ }^{25}$.

Combination of tri-butyl phosphate (TBP) and tri-octyl phosphine oxide (TOPO) in kerosene was also used for leaching of ${ }^{226} \mathrm{Ra},{ }^{210} \mathrm{~Pb},{ }^{238} \mathrm{U}$ and ${ }^{40} \mathrm{~K}$ form phosphogyp$\operatorname{sum}^{53}$. As a result of process optimization 92.1, 88.9, $83.4,94.6 \%$ of ${ }^{226} \mathrm{Ra},{ }^{210} \mathrm{~Pb},{ }^{238} \mathrm{U}$ and ${ }^{40} \mathrm{~K}$ respectively were successfully removed from the phosphogypsum. Using organic extractant under optimum conditions for treatment of the phosphogypsum waste, decontaminated product that can be safely used in many industrial applications was received.

Other very commonly encountered organic compounds applied for the extraction of rare earths include the HEHPA solution (2-ethylhexyl 2-ethylhexylphosphonic acid) in kerosene, where the compound functions as a liquid ion exchanger. The possibility of separation of middle rare earths thanks to the application of 1.0 $\mathrm{mol} / \mathrm{l}$ HEHEPA solution was confirmed, since the extraction process is based on ionic (proton) exchange. The highest coefficient of extraction was observed for $\mathrm{Tb}>\mathrm{Gd}>\mathrm{Eu}>\mathrm{Sm}^{26}$. Also the mixture of $\mathrm{D}_{2} \mathrm{EHPA}$ and HEH/EHP (2-(ethylhexyl) phosphonic acid mono2-ethylhexyl ester) demonstrates synergistic extraction of rare earths in sulphuric acid, similarly to the mixture of MEHPA and DEHPA, commonly known as Cyanex 272 for the separation of lanthanides, on the basis of the cationic ion exchange. The research works confirmed a better possibility of extraction of heavy metal rare earths, also from acidic solutions ${ }^{27}$.

One also proposes a method consisting in ion-exchange extraction with the application of resin globules similar to the ones applied in water softeners. As a result, one obtains chemically pure calcium sulphate, and the applied globules may be subject to regeneration with a solution of hydrochloric acid. In these research works, one observed the dependence between the ionic radius of an appropriate lanthanide and a possibility of inhibiting the growth of other crystals in a solution with a similar ionic radius (Fig. 4) ${ }^{28-29}$. Recent patents propose 


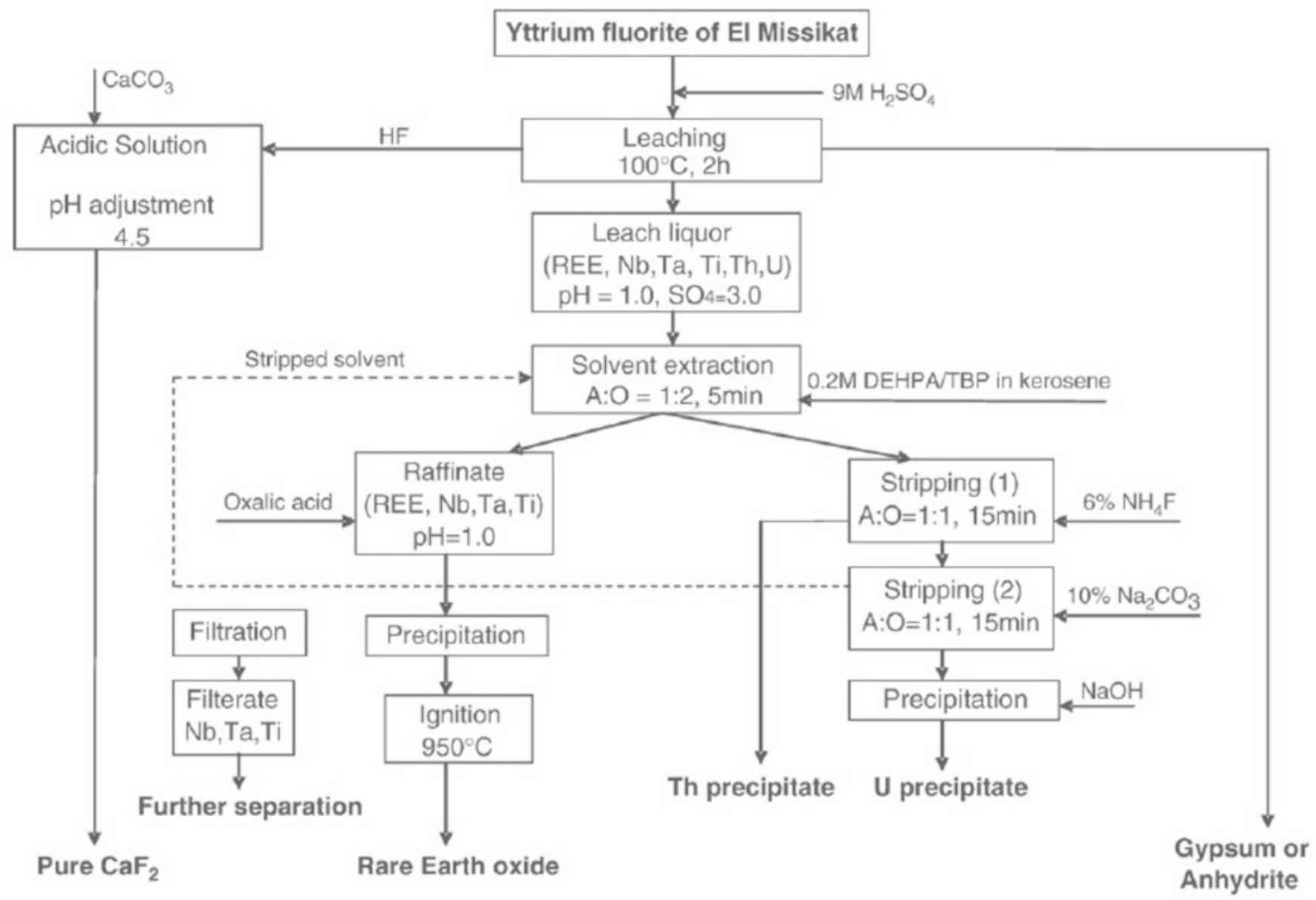

Figure 3. Scheme illustrating generation of rare earth oxides from phosphogypsum waste ${ }^{25}$

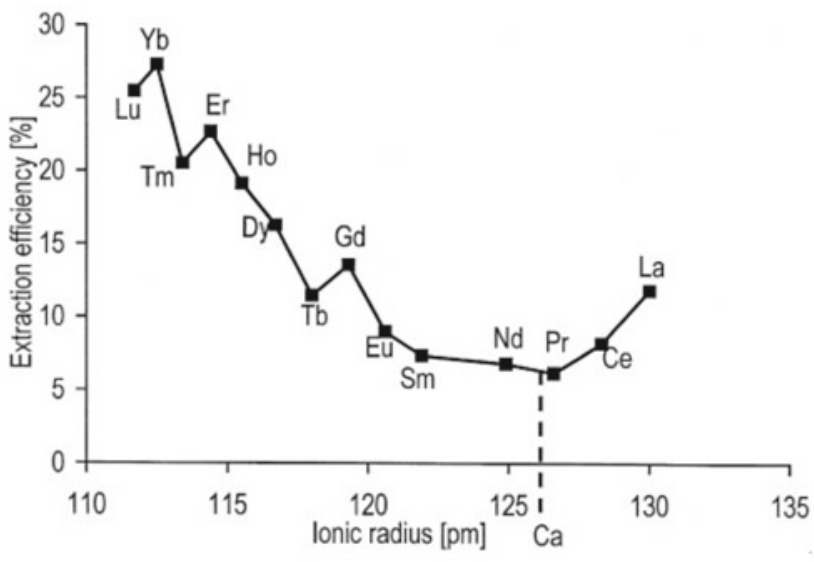

Figure 4. Extraction efficiency versus ionic radius of elements ${ }^{28}$

preparation of pulp from phosphogypsum and sulphuric acid or water before sorption of REM (rare earth metals $)^{51,52}$. Pulp from phosphogypsum and sulfuric acid solution with $\mathrm{pH}=0.5-2.5$ is prepared until achieving liquid to solid ratio of 4-7. Sorption of rare-earth elements is carried out directly from the phosphogypsum pulp on a sorbent with sulphuric acid functional groups, that effects in higher extraction of rare-earth elements, without a filtration step $^{51}$. In the second solution prior to sorption, phosphogypsum is crushed in water so that pulp is obtained with the solid to liquid ratio $1:(5-10)$. Sorbent containing sulfate and phosphate functional groups is used at the solid to sorbent ratio $1:(5-10)^{\mathbf{5 2}}$.

Rare earth metals recovery process can be also conducted by using chelating agents. A proposed method use hydrothermal leaching of phosphogypsum with aqueous solution of chelating agents and separation of rare earth metals from such solution. Authors claim that presented solution does not require any special equipment and is less corrosive than separation of rare earth sulfates ${ }^{47}$.

Another solutions use cation exchangers for rare earth metal separation ${ }^{\mathbf{4 8}, \mathbf{5 0}, \mathbf{5 4}}$. At the first step, phosphogypsum is leached with sulfuric acid. REM concentrate is extracted from the solution by crystallization and fed to REM and phosphorus leaching stage. Prior to leaching phosphogypsum is subjected to washing with water to obtain solution containing REM and phosphorus. Insoluble residue is washed before processing, by calcium compound, to produce pulp with $\mathrm{pH}$ not over that of REM phosphate precipitation. REM is sorbed on cation exchangers and after desorption is sent to REM concentrate production stage. Phosphorus and associated impurities are deposited from sorption mother pulp. Obtained pulp is separated as an residue for further recovery ${ }^{\mathbf{4 8}}$. In other patented solution for sorption of rare-earth elements sulfoxide cationite is used. Invention enables to remove phosphorus, fluorine and sodium impurities from phosphogypsum while ensuring a high degree of extraction of rare-earth elements, reduces consumption of sulfuric acid and calcium-containing reagent ${ }^{49}$. Using sulfocationite in hydrogen or ammonia form with further desorption of rare-earth elements with ammonia sulphate solution, extraction of rare-earth elements of medium and yttrium groups to concentrates was $41-67 \%$ and $28-51.4 \%$ respectively ${ }^{54}$. 
Biotechnological methods of processing phosphogypsum are also reported for rare earth elements recovery ${ }^{55,56}$. Acidophilic thionic bacteria in the active growth phase (bacterial population of 107 cells $/ \mathrm{ml}$ ) leached phosphorus and rare-earth elements under aerobic condition during 3-30 days, at temperature $15-45^{\circ} \mathrm{C}$ and solid-to-liquid ratio 1:5-1:955. Rare earth elements and phosphorus is transferred to the liquid phase. The resulting cake is treated with an aqueous solution, containing potassium carbonate as an alkali metal carbonate, heated followed by separation of calcium carbonates and strontium ${ }^{\mathbf{5 6}}$.

\section{CONCLUSIONS}

Phosphogypsum is undoubtedly a noxious industrial waste contributing to global environmental and economic problems. The possibilities of its waste-free processing are large, however they require the application of suitable technologies, frequently expensive ones, and allowing for the individual characteristics of the given waste.

Taking into consideration the lack of direct possibility of implementing global methods for recovering rare earths from domestic phosphogypsum, it is sensible to devise effective technologies permitting the management of newly created and already deposited waste. Among the currently applied methods, extractions with the application of organic compounds prevail, however the fact should be noted that the more selective solvent is chosen for a reaction, the higher its price will be. Therefore, regarding the so far discussed methods for the processing of phsosphogypsum, the most promising ones include those based on initial purification of phosphogypsum through the precipitation of impurities, selective separation of rare earths with the application of liquid membranes, and subsequently the final purification of the material with the use of ionic liquids.

The research works conducted so far confirm the possibility of applying phosphogypsum for the recovery of lanthanides, and the process enhances the removal of remaining impurities, thanks to which the purified calcium sulphate (gypsum) may find application for the production of construction materials. These activities permit not only to reduce the phosphogypsum heaps deposited in Poland, but also to eliminate the need to import valuable concentrates of rare earths from other countries.

\section{LITERATURE CITED}

1. Kijkowska, R. (1988). Rare Earths in phosphogypsum from the processing of apatite, Monograph 74, Poland: Cracow University of Technology (in Polish).

2. Jarosiński, A. (2001). The rules for complex development of the secondary deposits on the example of economic use of apatite phosphogypsum, Scientific Books of Cracow University of Technology, series Engineering and Chemical Technology, No. 27, Cracow (in Polish).

3. Resolution of the Council of Ministers No. 127 from December 24, 2010 about 'National Waste Management Plan for 2014' M.P. $2010 \mathrm{Nr} 101$ poz. 1183, Retrieved January 14, 2013, from http://isap.sejm.gov.pl/DetailsServlet?i$\mathrm{d}=$ WMP20101011183

4. „Who are afraid of Chinese prices for elements”, Retrieved January 12, 2013, from http://wyborcza.biz/biznes/2029020,101562,8428192.html (in Polish).
5. „Growing contraband of rare earth metals, and Poland?”, Retrieved January 14, 2013, from http://www.sztolnie.podziemia.eu/index.php/news/28-rosnie-przemyt-metali-ziem-rzadkich (in Polish).

6. „Growing concern about the decreasing resources of transition metals and rare-earth metals", Retrieved January 14, 2013, from http://forsal.pl/artykuly/395923,rosna_obawy_o_skape_zasoby_metali_przejsciowych_i_metali_ziem_rzadkich.html (in Polish).

7. Study on Rare Earths and Their Recycling, Final Report for The Greens/EFA Group in the European Parliament, January 2011.

8. The What and Why of Rare Earth Metals, The Gold Report, Retrieved March 28, 2012, from http://www.theaureport. com/pub/na/8595

9. Kong, L., Hu, H., Wang, T., Huang, D. \& Fu, J. (2011). Synthesis and surface modification of the nanoscale cerium borate as lubricant additive, J. Rare Earths. 29(11), 1095-1099. DOI: 10.1016/S1002-0721(10)6065-9.

10. Ramatowski, T., Serafin, M. \& Kawalec, M. (2011). Spheroidization of vanadium carbide in Fe-C-V alloys, STAL Metale \& Nowe Technologie. 11(12), 31-33. (in Polish).

11. Wang, M., Chen, L., Wang, Z. \& Bao, E. (2012). Effect of rare earth addition on continuous heating transformation of a high speed steel for rolls, J. Rare Earths. 30(1), 84-89. DOI: 10.1016/S1002-0721(10)60644-8.

12. Xing, S., Yu, S., Deng, Y., Dai, M. \& Yu, L. (2012). Effect of cerium on abrasive wear behaviour of hardfacing alloy, $J$. Rare Earths, 30(1), 69-73. DOI: 10.1016/S1002-0721(10)60641-2.

13. Hao, F., Liao, B., Li, D., Liu, L., Dan, T., Ren, X. \& Yang, Q. (2011). Effects of rare earth oxide on hardfacing metal microstructure of medium carbon steel and its refinement mechanism, J. Rare Earths, 29(6), 609-613. DOI: 10.1016/ S1002-0721(10)60507-8.

14. Fan, J., Chen, Z., Yang, W., Fang, S. \& Xu, B. (2012). Effect of yttrium, calcium and zirconium on ignition-proof principle and mechanical properties of magnesium alloys, $J$. Rare Earths, 30(1), 74-78. DOI: 10.1016/S1002-0721(10)60642-4.

15. Mineral Commodity Summaries 2012, U.S. Geological Survey, January 2012, p. 128-129, Retrieved March 28, 2012, from http://minerals.usgs.gov/minerals/pubs/mcs/2012/mcs2012.pdf

16. Runowski, M., Grzyb, T. \& Lis, S. (2011). Bifunctional luminescent and magnetic core/shell type nanostructures Fe3O4@CeF3:Tbe3+/SiO2. J. Rare Earths, 29(12), 1117-1122. DOI: 10.1016/S1002-0721(10)60609-6.

17. Sułowicz, W. \& Sobaszek-Pietras, M. (2008). Fosrenol-new options in treatment of hyperphosphemia in chronic kidney disease, Nefrologia i dializoterapia polska, Wydaw. Prz. Lek. 2, 113-118. (in Polish).

18. Zhang, J., Sun, J., Gu, G., Hao, X., Liu, D., Li, Y. \& Qin, X. (2012). Effect of La+3 on osteogenic and adipogenic differentiation of primary mouse bone marrow stromal cells, J.Rare Earths 30(1), 90-93. DOI: 10.1016/S10020721(10)60645-X.

19. Zhang, J., Liu, D., Sun, J., Zhang, D., Shen, S. \& Yang, M. (2009). Effect of $\mathrm{Dy}^{+3}$ on osteogenic and adipogenic differentiation of mouse primary bone marrow stromal cells and adipocytic trans-differentation of mouse primary osteoblasts, Chin. Sci. Bull., 54(1), 66-71. DOI: 10.1007/S11434-008-0503-2.

20. Liu, L., Wang, S., Huang, Y., Zhou, Y., Tong, Y. \& Chen, X. (2011). Enhancin water repellence and mechanical properties of antibacterial gelatin/Ce(III) fiber by heat treatment, J. Rare Earths, 29(11), 1084-1088. DOI: 10.1016/S1002-0721(10)6063-5.

21. Kijkowska, R., Kowalczyk, J., Mazanek, C. \& Mikołajczyk, T. (1989). Fundamentals of non-waste processing of apatie phosphogypsum, Scientific Works of Wrocław University of Technology 59, monograph 28, Wrocław, Poland. (in Polish)

22. Yang, J., Liu, W., Zhang, L. \& Xiao, B. (2009). Preparation of load-bearing building materials from autoclaved phosphogypsum, Constr. Build. Mater. 23 687-693. DOI: 10.1016/j. conbuildmat.2008.02.011. 
23. Wang, L., Long, Z., Huang, X., Di, Y., Cui, D. \& Zhang, G. (2010). Recovery of rare earths from wet-process phosphoric acid, Hydrometallurgy 101, 41-47. DOI: 10.1016/j. hydromet.2009.11.017.

24. Pei, L., Wang, L. \& Yu, G. (2012). Study on a novel flat renewal supported liquid membrane with D2EHPA and hydrogen nitrate for neodymium extraction, J. Rare Earths, 30 (1), 63-68. DOI: 10.1016/S1002-0721(10)60640-0.

25. Ibrahim, T.M.M. \& El-Hussaini, O.M. (2007). Production of anhydrite-gypsum and recovery of rare earths as a by-product, Hydrometallurgy 87, 11-17. DOI: 10.1016/j.hydromet.2006.11.017.

26. Fontana, D. \& Pietrelli, L. (2009). Separation of middle rare earths by solvent extraction using 2-ethylhexylphosphonic acid mono-2-ethylhexyl ester as an extractant, J. Rare Earths, 27(5), 830-833. DOI: 10.1016/S1002-0721(08)60344-0.

27. Zhang, Y., Li, J., Huang, X., Wang, C., Zhu, Z. \& Zhang, G. (2008). Synergistic extraction of rare earths by mixture of HDEHP and HEH/EHP in sulfuric acid medium, $J$. Rare Earths, 26(5), 688-692. DOI: 10.1016/S1002-0721(08)60164-7.

28. Koopman, C. \& Witkamp, G.J. (2000). Extraction of lanthanides from the phosphoric acid production process to gain a purified gypsum and a valuable lanthanide by-product, $H y$ drometallurgy 58, 51-60. DOI: 10.1016/S0304-386X(00)00127-4.

29. Koopman, C. \& Witkamp, G.J. (2002). Ion exchange extraction during continuous recrystallization of CaSO4 in the phosphoric acid production process: lanthanide extraction efficiency and CaSO4 particle shape, Hydrometallurgy 63, 137-147. DOI: $10.1016 / \mathrm{S} 0304-386 \mathrm{X}(01) 00219-5$.

30. Degirmenci, N. (2008). The using of waste phosphogypsum and natural gypsum in adobe stabilization, Constr. Build. Mater. 22, 1220-1224. DOI: 10.1016/j.conbuildmat.2007.01.027.

31. Zhou, J., Gao, H., Shu, Z., Wang, Y. \& Yan, Ch. (2012). Utilization of waste phosphogypsum to prepare non-fired bricks by a novel Hydration-Recrystallization process, Constr. Build. Mater. 34, 114-119. DOI: 10.1016/j.conbuildmat.2012.02.045.

32. Altun, I. \& Sert, Y. (2004). Utilization of weathered phosphogypsum as set retarder in Portland cement, Cement Concrete Res. 34, 677-680. DOI: 10.1016/j.cemconres.2003.10.017.

33. Kacimi, L., Simon-Masseron, A., Ghomari, A. \& Derriche, Z. (2006). Reduction of clinkerization temperature by using phosphogypsum, J. Hazard. Mater. B137, 129-137. DOI: 10.1016/j.jhazmat.2005.12.053.

34. Huang, Y. \& Lin, Z. (2010) Investigation on phosphogypsum-steel slag granulated blast-furnance slag-limestone cement, Constr. Build. Mater. 24, 1296-1301. DOI: 10.1016/j. conbuildmat.2009.12.006.

35. Górecki, H., Chojnacka, K., Dobrzański, Z., Kołacz, R., Górecka, H. \& Trziszka, T. (2006). The effect of phosphogypsum as the mineral feed additive on fluorine content in eggs and tissues of laying hens, Anim. Feed Sci. Tech. 128, 84-95. DOI: 10.1016/j.anifeedsci.2005.10.001.

36. Jorjani, E., Bagherieh, A.H. \& Chelgani, S.Ch. (2011). Rare earth elements leaching from Chadormalu apatite concentrate: Laboratory studies and regression predictions, Korean J. Chem. Eng. 28(2), 557-562. DOI: 10.1007/s11814-010-0383-4.

37. Gasquez, J.A., DeLima, E., Olsina, R.A., Martinez, L.D. \& Guardia, M. (2005). A fast method for apatite selective leaching from granitic rocks followed through rare earth elements and phosphorus determination by inductively coupled plasma optical emission spectrometry, Talanta 67, 824-828. DOI: $10.1016 /$ j.talanta.2005.04.008.

38. Binnemans, K. \& Jones, P.T. (2014). Perspectives for the recovery of rare earths from end-of-life fluorescent lamps, J. Rare Earths. 32 (3), 195-200. DOI: 10.1016/S1002-0721(14)60051-X.

39. Binnemans, K., Jones, P.T., Blanpain, B., Gerven, T.V., Yang, Y., Walton, A. \& Burchert, M. (2013). Recycling of rare earths: a critical review, J. Clean. Prod. 51, 1-22. DOI: 10.1016/j.jclepro.2012.12.037.
40. The balance of Polish and World minerals in 2009 (1 st ed.). Institute of Mineral and Energy of the Polish Academy of Sciences, Laboratory of Mineral Policy, Cracow 2011 (in Polish).

41. Podbiera-Matysik, K., Gorazda, K. \& Wzorek, Z. (2012). The ways of rare earth elements applications and obtaining, Tech. Trans. 16, 147-156 (in Polish).

42. Brzyska, W. (1996) Lanthanides and actinides (2 nd ed.), Contemporary Inorganic Chemistry, Warsaw: Publisher Scientific-Technical (in Polish).

43. Góralczyk, S. \& Uzunów, E. (2013). The recovery of yttrium and europium compounds from waste materials, Arch. Environ. Prot. 39(3), 107-114. DOI:10.2478/aep-2013-0023.

44. Walczak, J. Rychłowska-Himmel, I., Kurzawa, M., Górnicki J. \& Dębiński, H. (1995). Method of obtaining Rare Earth Element concentrate from phosphogypsum, Polish Patent PL 178169.

45. Abramov, A.M., Galieva, Z.N., Galiev, R.S., Sabinina, O.R. \& Sobol, J.B. (2013), Method for extracting rare earth metals from phosphogypsum, Patent No.WO 2013100823 A2.

46. Xie, H, Ren, L., Yang, B., Lai, B. \& Tan, C. (2013). Mineral fertilizer containing active phosphorus slag and manufacture method thereof, Patent No. CN102976862 (A)

47. Yasuhiro Konishi, Saito Hansan, Masaya Toda, Toshihiko Okumura (2014). Method For Recovering Rare Earth, Patent No. JP 2014009395 (A).

48. Fokin, K.S. \& Nesterova, E.O. (2013). Method Of Extracting Rare-Earth Metals (Rem) From Phosphogypsum, Patent No. Ru2492255 (C1).

49. Lokshin, E.P., Tareeva, O.A. \& Kalinnikov, V.T. (2013). Method of processing phosphogypsum, Patent No. Ru2487083 (C1).

50. Fokin, K.S. \& Nesterova, E.O. (2014).Method of processing phosphogypsum, Patent No. RU2504593 (C1).

51. Rychkov, V.N., Kirillov, E.V., Smirnov, A.L., Jazev, V.A. \& Ivan Ko, V.A. (2013), Method Of Extracting Rare-Earth Elements From Phosphogypsum, Patent No. RU 2473708 (C1).

52. Kolyasnikov, S.V., Borisov, M.M., Kirillov, E.V. \& Rybina, M.L. (2012) Extraction Method Of Rare-Earth Metals From Phosphogypsum, Patent No. RU 2471011 (C1).

53. El-Didamony, H., Gado, H.S., Awwad, N.S., Fawzy, M.M. \& Attallah, M.F. (2013). Treatment of phosphogypsum waste produced from phosphate ore processing, J. Hazard. Mater. 244-245, 596-602. DOI: 10.1016/j.jhazmat.2012.2012.10.053.

54. Lokshin, E.P., Tareeva, O.B. \& Kalinnikov, V.T. (2012). Method of phosphogypsum processing for manufacture of concentrate of rare-earth elements and gypsum, Patent No. Ru2458999 (C1).

55. Bashlykova, T.V., Zhivaeva, A.B., Ashirbaeva, E.A., Danil'chenko, L.M. (2012). Method of processing phosphogypsum with extraction of rare-earth elements and phosphorus, Patent No. RU2010143835 (A).

56. Bashlykova, T.V., Val'kov, A.V., Zhivaeva, A.B., Pakhomova, G.A., Ashirbaeva, E.A., Danil'chenko, L.M. \& Petrov, V. I. (2012). Method of processing of phospho-gypsum, Patent No. RU2010144166 (A). 